\title{
Beyond Racial Divisions Bridges and Intersections in the Spanish Colonial Philippines
}

This article aims to explore some factors, moments, spaces, and people that acted as bridges and intersections between different population groups in Philippine colonial society during the final decades of the nineteenth century, in order to analyze the permeability of the borders that separated and classified the inhabitants of the Philippines. To this end, this study reviews the legal status according to which the population living in the Philippines was divided and the social structure that shaped Philippine society. It analyzes as well some collaborations and relationships established in the political scene, in the economic and professional world, and in daily life. 


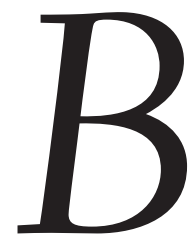

rains of the Nation, the seminal volume written by Resil Mojares (2006), helped me, among many other things, to better understand the world of creoles and Spanish mestizos in the Philippines-a segment of the population that has been paid but little attention to date, but through which can be analyzed an issue that I am interested in, that is, the degree of permeability of the borders that separated the population in the nineteenthcentury Philippines.

The Philippines of the late nineteenth century could be seen as a colonial society formed by colonizers and colonized, but also by some others that, strictly speaking, never belonged to any of those groups, remaining outside colonial society. A distinct legal and fiscal division marked the position of each person within that colonial society. At the same time, there also existed a social structure in which different population groups could be distinguished. However, a closer study of that colonial society allows us to perceive channels for interaction and exchange, which at times made it possible for individuals to transcend the legal and social divisions that compartmentalized the population. For this reason, in this homage to Resil Mojares, I explore some factors, moments, spaces, and people that served as bridges and intersections between different groups in the Philippines during the final decades of the nineteenth century.

For this purpose, I review, firstly, the legal and tax status according to which the population living in the Philippines was divided into categories. Secondly, I define the social structure that shaped late-nineteenth-century Philippine society, briefly characterizing each sector and highlighting the emergence of new population groups. And, thirdly, I examine some collaborations and relationships established in the political scene, in the economic and professional world, and in daily life, all of which show that the division of colonial society was not as rigid as the laws and racial categories established, but that interactions often occurred, allowing legal and social categories to be transcended and offering us a richer and more complex idea of colonial society.

The perspective of this study was born out of two research projects: the first one dealing with the analysis of coexistence and collaboration between communities in the late nineteenth-century Philippines, and the second one involving the evolution of a creole family in the Philippines during that same century. Both research projects were based on sources from multiple 
archives (Elizalde and Huetz de Lemps 2017; Elizalde et al. 2019). These projects allowed the hypothesis to be reaffirmed that colonial Philippine society could be seen not in black and white terms, as if it were composed of sectors rigidly separated by legal criteria based on race, but in a nuanced way in which it is possible to detect that these sectors had frequent exchanges, and members of population groups sometimes went through the borders that separated them, borders that came out more permeable than they appeared to be in theory. It is precisely those transfers between groups that are explored in this article.

\section{The Legal Status of the Population}

The old Laws of the Indies (Leyes de Indias), by which the Spanish empire was ruled since the sixteenth century and which were also applied in the Philippines, divided society into two "republics": a republica de españoles and a republica de indios, each having its own institutions and governmental apparatus. In accordance with a strict social and racial hierarchy, each group had different duties, but also rights guaranteed by the Laws of the Indies.

In a recognized work followed by many authors, Edgar Wickberg (1964, 62-64) pointed out that, during the colonial era, the population of the Philippines was divided into four basic legal and racial categories (cf. Doeppers 2000, 266, 268; Blanco 2011, 359; Luque and Fernández 2016, 331, 336; Aizpuru 2017, 338; Huetz de Lemps 2018, 193; Elizalde 2018a, 251). First were the Spaniards, understood in a broad sense, including those born on the Peninsula and their descendants born in the Philippinespeninsulares, criollos, and mestizos de español (peninsulars, creoles, and Spanish mestizos) - who neither paid taxes nor provided compulsory labor services. Second were the indios or native inhabitants of the Philippines, who paid the lowest taxes and had to provide compulsory personal work. Third were the Chinese mestizos, who paid around double the indio's tribute (based on a theoretical greater ability to generate wealth) and also had to provide forced labor services. This category of Chinese mestizos, as a separate and well-defined group, has been analyzed and characterized by Edgar Wickberg (1964), Richard Chu (2010), and Michael Cullinane (1982, esp. 257; 2013; 2017, 297-318, esp. 317), who explained their special role in Philippine history. Finally, there were the Chinese, who paid the highest tribute, again in response to their wealth-creating abilities, but who did not have to provide labor services owing to the difficulties involved in 
enforcing these duties upon them. It is important to highlight the relevance that the Chinese world had in the Philippines to the point of having them merit two scales in the classification system of the population. ${ }^{1}$

To these four categories could be added two other groups on the margins of colonial society. First were the infieles (infidels), consisting either of the Muslim population, who inhabited the southern Philippine islands, or the Negritos and other population groups, who lived on the mountains or beyond the borders of the colonial society. Both of these groups were outside the norms of colonial power. For many years, the Spaniards believed that these groups could neither be integrated into the colonial system nor made to adopt its laws and pay taxes. Despite these considerations, attempts were made to push these boundaries and take the colonizing and evangelizing effort further, especially during the nineteenth century. The relationship with the southern Philippine islands, which were thoroughly Islamized, was especially problematic. Even while being from a different world, the inhabitants of the southern islands exercised considerable influence on the archipelago, in spite of the colonial state's frequent confrontations with them for their piratical raids launched against other islands, the treaties they signed with other countries, and their general disregard for Spanish authority (Warren 2002; Barclay 2003, 217-55; Amoroso 2003, 118-47; Luque 1997, 209-46).

The last group consisted of foreigners, excluding the Chinese, who as I have noted were considered most of the time as a special group. ${ }^{2}$ Until the first decades of the nineteenth century, nationals of other countries could not settle officially on the islands, but once authorized by different decrees (the most significant from 1841) they played an important role in the archipelago, especially in its economy. They were not subject to Spanish sovereignty, but they had to respect it and obey Spanish law until a specific regulation for them was enacted in 1870 . Some of these foreigners underwent naturalization to become Spanish subjects in order to benefit from the legal and economic privileges of this situation; the eligibility criteria included a long period of residence, possessing a house and real estate worth a certain value, marrying a Spanish or a Philippine woman, being Catholic, taking an oath of loyalty to Spain, and having the application endorsed by the local authorities (Aizpuru 2017, 325-62; Clarence-Smith 2017, 363-91).

In addition to paying different taxes and labor services, each of these categories of people had different levels of access to colonial and local government institutions and to various rights concerning matters such 
as choice of residence, mobility, land ownership, economic activity, and legal status. As such, the colonial taxonomy of the islands situated every individual in their place in the hierarchy-a position that entailed obligations and imposed limits on the rights and aspirations of non-Spanish social groups - within a system that reaffirmed the inequality between the different population groups. However, despite the fact that in the Philippine archipelago this division never came to be denied, it became more diffused over time, as new channels for social reconfiguration emerged, as this article seeks to show.

\section{The Social Structure}

Parallel to the legal and ethnic categories we have just seen was a social structure that shaped the Philippines during the closing decades of the nineteenth century and revealed the existence of different social groups. These social groups were based not only or exclusively on race, but also on social, political, economic, or professional status, which frequently overlapped, all of which contributed in their own way to the transformation of the archipelago.

Within the category of Spaniards it was possible to define a first group constituted by the Spanish born in the Peninsula, who generally resided in the islands because of their position in the colonial administration. They were mostly employed or financed by the Spanish government: civil servants, military men, members of the church, and professionals working for educational, technical, or medical institutions. Others were partners and representatives of commercial and investment firms, or small entrepreneurs who served the needs of the colony. Often they resided on the islands only throughout the duration of their terms of office, until either they completed their assignment or had secured their intended administrative or economic objectives. Others left the islands upon retirement to return to Spain and reunite with their families. In some cases, however, they remained in the Philippines for life and became a part of the world of the Philippine islands (Elizalde 2003, 2009; Elizalde and Huetz de Lemps 2015).

Also within the category of the Spaniards could be identified a second group formed by the descendants of Spaniards: the creoles and Spanish mestizos who were born in the Philippines. They had the same legal status, rights, and duties as the Spanish born on the Peninsula. In the terminology of that time, rather than creole or Spanish mestizos, they were known as 
españoles filipinos or hijos del país (sons of the country), which emphasized the Philippines as their birthplace. Only after the nationalistic struggle of the ilustrados, the "enlightened" early nationalists, was the word "Filipino" used to refer to the population of the islands as a whole, although the concept had already been used in this sense from the beginning of the nineteenth century by some of these Spanish creoles and mestizos (AHN 1842; Llobet 2011, chs. 1 and 6). In theory, creoles were different from mestizos in that the former were descendants of Spaniards on both sides, paternal and maternal, whereas the mestizos were generally of Spanish or creole descent on their fathers' side and had Philippine native, Spanish mestizo, or Chinese mestizo mothers. As such, the division was based on whether or not the individual was of mixed origins. These groupings were ultimately based on the old "purity of blood" arguments, which were reactivated by a "racializing" colonial discourse that aimed to distinguish between Spanish-born citizens and creoles, on one side, and Spanish mestizos, on the other side, which led progressively to the political, social, and economic marginalization of the latter group. For obvious reasons, the Spanish-born and the creoles had no interest in being considered equal to the mestizos, especially if the "mixing of bloods" had taken place long in the past (Montero y Vidal 1886, 138; Retana 1921, 90; Bowring 1876, 113-41; Nolasco 1970; Joaquin 2005; Mojares 2006; Llobet 2011; Elizalde and Huetz de Lemps 2017).

Racial differentiation continued to be a fundamental factor in defining the position of each person in Philippine colonial society, which different officials and writers continued to underline in order to justify the colonial state and the existing discrimination. ${ }^{3}$ In practice, however, race was not the only factor at play in the differentiation between creoles and Spanish mestizos and among other population groups. Many individuals who, based on descent, should have been considered mestizos were regarded as creole instead. The distinction not only relied on racial criteria, but also on other factors such as belonging to certain social and family networks, the individual's level of wealth, or professional activity. Being in one or the other category was an important social marker because it affected matters such as access to official positions, participation in institutions, and social standing (Elizalde 2017a, 2017b, 2018a; Huetz de Lemps 2017, 2018).

Many examples of this situation can be pointed out, but I will highlight only the case of Pedro Pablo Róxas y Castro, one of the most outstanding 
creoles of the nineteenth century. Although of Spanish descent, he belonged to the fourth generation of his family born in the Philippines. For several generations, his peninsular ancestors interbred with Spanish mestizos, Chinese mestizos, and even with natives. His paternal greatgrandmother was María Vita Pitto, sister of Manuel Bonifacio Pitto, one of the principales (chiefs) of the Chinese mestizo gremio (corporate council based on ethnicity) of Santa Cruz, who came from a wealthy family of Chinese merchants (NAP 1820). His maternal grandmother was Juana de Castro y Ocampo, daughter of españoles filipinos in Cavite, who descended from a creole married to a native or Chinese mestiza. In some sources, she also appeared as Juana Lim de Castro, which suggested Chinese ancestry. ${ }^{4}$ Therefore, strictly speaking, Pedro P. Róxas should have been considered a mestizo español filipino; yet, he was considered a creole. His economic and social position and the networks in which he was integrated led him to qualify as a creole, which facilitated his incorporation into leading positions in the political and economic administration of the Philippines (Elizalde et al. 2019).

Owing to widespread mixing over the generations, certain creoles and many mestizos no longer looked Caucasian, but were visibly of mixed stock. The way in which their phenotypical features were regarded varied from person to person, depending on the social networks and groups to which they belonged and the tolerant or intolerant nature of their immediate social circle. In any case, Philippine colonial society was remarkably flexible on this issue, which did not always become decisive in determining the place of a person in colonial society, although later, in trips to the Peninsula or to other places in Europe, people who had different skin color or facial features would have received a different treatment from that which they received on the archipelago (Huetz de Lemps 2018; Aguilar 2016).

In light of the aforementioned, I return to the case of Pedro P. Róxas. He had been moving among the Manila elites for many years, and when he travelled to Spain or to the rest of Europe he had always been considered as a member of these transnational business elites, or as a regidor (councilor) of the Manila city council and a member of the Consejo de Administración de Filipinas, without anyone ever commenting on his racial origins or personal physical features. However, after the outbreak of the Philippine Revolution in August 1896, he was accused of supporting the insurrection. Róxas went into exile to avoid arrest and possible execution, just as it 
had been the case with other persons in his closest circle. On his way to exile, Róxas came to be described by the French consul in the Philippines as "mestizo" (AMAEP 1896a) and even as an indígena (native) (AMAEP 1896b), after being considered a filibustero who opposed the colonial regime.

The nineteenth century also witnessed the configuration of a new native society in the Philippines. This society did not consist of "children to be taught" or "savages to be civilized," as claimed by the legitimizing discourse of the colonial regime and by the arguments that supported the differentiation of Spanish and natives - a theme that received great attention in the closing decades of the nineteenth century to prevent the advance of the non-Spanish population. However, by the nineteenth century, the Philippines was already a country with developed elites, where new social classes had emerged and a national consciousness had begun to form out of a deep diversity of population groups (Blanco 2011, 356-94; Fradera 2016, 1123-29; Elizalde 2012, 148-60).

The autochthonous population was a complex construct that encompassed over fifty ethnic groups and various languages, cultures, and religions: from the inhabitants of Luzon island and the Visayans who lived in the central islands of the archipelago; the Aeta and the Igorot, who occupied the mountainous areas; to the Muslims of the southern islands; from the traditional political elites and the ilustrados from Manila, Cebu, and Iloilo; a powerful Chinese mestizo group, increasingly integrated into the native world; a new class of urban workers; and the rural population; to groups with close foreign connections. Many of these groups joined colonial society, but others remained on the margins and lived in their own world.

Among the native population, the indigenous principalia (local chiefs) stood. Owing to their traditional control over political, economic, fiscal, and legal power in local governments, they remained at the zenith of native Philippine society. During the nineteenth century, they constantly demanded from the colonial state new opportunities for the archipelago, a greater role for the natives in the colonial regime, and rights equal to those of the Spanish. Similarly, they became increasingly vocal in their opposition to the part played by religious orders in municipal life. At the same time, the end of the hereditary nature of the position of the gobernadorcillos (municipal mayors chosen from the principalía and integrated into the colonial structure) and the creation of new local councils allowed new social groups to access the political game. In 1789 a royal decree established that provincial governors 
were to appoint barangay chiefs. Although the local principalía maintained an advisory role in these appointments, the post was no longer considered hereditary, which meant the position was open to a wide array of candidates, not only to the members of the principalía. This measure not only created a large base of candidates, but it also exacerbated power struggles at the local level. Population growth and the increasing size of settlements led to the creation of new boroughs and, therefore, of new positions of political and economic preeminence at the local level. This process often resulted in conflict between the traditional elite, who opposed municipal segregation and the subsequent fragmentation of power, and the new social sectors that aspired to grasp some of that power (Phelan 1959; Owen 1974; Constantino 1985; Guerrero 1977; Larkin 1982, 595-628; Bankoff 1992, 679-700; Huetz de Lemps 2006, 72, 78; Sánchez 2010; Javellana 2017).

Similarly, as Cullinane (2003, 1-48) has pointed out, the differences between different native elites were accentuated: on one side, the rural elites of the villages, almost always indigenous; on the other side, the provincial elites, usually natives and mestizos, who dominated larger towns and provincial capitals and who possessed extensive rural holdings; and, finally, the urban elites of Manila, Cebu, or Iloilo, descendants of Spanish and Chinese mestizos, who owned large haciendas and were increasingly involved in business concerns in partnership with Spanish-born and foreign agents.

In addition, a new elite composed of creole, Chinese mestizo, and native landowners and merchants began to consolidate and increase their economic and political influence from the late eighteenth century onward. The economic power of this group relied chiefly on export agriculture, and they dealt not only with Spanish merchants, who should have acted as middlemen between the colony and the international markers, but also directly with British, German, and American firms and Chinese traders as well as with interregional, inter-Asiatic, an international networks.. These elites formed a heterogeneous group, and their interests often differed depending on their geographical origin, economic sectors, land ownership regimes, and production systems. Often they had a multiethnic racial origin. However, despite their differences, they progressively crystallized as a new and diverse social and economic group, and from their different positions they promoted changes in the Philippines and were therefore fundamental in forging a new national project (McCoy and De Jesus 1982; De Jesus 1980; Larkin 1993; Owen 1984; Legarda 1999; Aguilar 1998; Corpuz 1999; Elizalde 2017a). 
Often intertwined with these groups was a new Philippine-educated class of people, who frequently complemented their education in Spanish and other European universities. This group of ilustrados was instrumental in the development of a Philippine national consciousness. They followed international events and believed in the liberal political ideals of the time. Their publications criticized the injustice and arbitrariness of the colonial regime, demanded social equality and opportunities for the Philippines, promoted social regeneration for the sake of national construction, and increasingly opposed the interference of religious orders in the life of the archipelago. In the beginning, these demands did not include a reappraisal of the archipelago's relationship with Spain, but the lack of response from the colonial administration led them increasingly to demand self-government and, later, independence (Schumacher 1997; Mojares 2006; Thomas 2012; Hau 2017; Kalaw 1926; Constantino 1969; Corpuz 1989).

The nineteenth century also reaffirmed the importance of the peasant class, which was made up of individuals who were economically less powerful but were keenly aware of the need to demand their rights from the colonial administration, the religious orders (which were major landowners), and the native, mestizo, or Spanish landowners who imposed harsh working conditions on their properties' workforce.

Alongside the emergence of this peasant class, the creation of new industries and commercial firms and the burgeoning service sector also led to the emergence of incipient urban-based working and professional classes, composed of lawyers, clerks, employees of the colonial bureaucracy and merchant houses, shopkeepers, primary and secondary schoolteachers, artisans and artists, architects, and other workers (including women, as the cigarreras employed in the tobacco industry), many of whom played a critical role in the political events of the late nineteenth century and the time of revolution (Cullinane 2003, 18).

Another group that contributed greatly to the affirmation of a Philippine national identity and the struggle for equality was the native clergy, who had a conflictive relationship with the colonial administration. From the early nineteenth century onward, the colonial rulers had tried, in response to the request of the religious orders, to quell the influence of native clergymen upon the population by severely limiting their action in their parishes. This conflict peaked in 1872 when, following the Cavite Mutiny, three popular secular priests, Mariano Gómez, José Apolonio Burgos, and Jacinto Zamora, 
were accused of being behind the rebellion and executed. These events and the widespread feeling of subjugation led to the propagation of strong nationalistic sentiments among the native clergy, which resulted in their wholehearted support for the 1896 rebellion (Schumacher 1981, 1991, 2011; Blanco 2010, 2013).

Also significant were a number of local populist religious movements, which advocated religious practices midway between folk-inspired forms of Catholicism and deeply rooted pagan and animistic beliefs. In some contexts these movements played an important role in mobilizing the most unprivileged sectors of the Philippine population (Ileto 1979; Blanco 2009; McCoy 2017).

\section{Borders and Interactions in the Nineteenth Century}

In this context, the nineteenth century was a time of change and of creating new social arenas. As I have explained, the Philippines was subject to a colonial regime in which the colonial authorities controlled the policies and rules of the game. There were laws that established different population categories and fixed different rights, obligations, and possibilities for each one. The inequality was manifest and intentional to keep the power in the hands of a few and to justify the colonial regime and the different treatment given to the different population groups.

Some factors contributed, however, to bridge these divisive cracks in the system. On the one hand, to maintain control and avoid local revolts, the authorities were forced to seek new balances and offer some compensation to the native population in exchange for their acceptance of the colonial regime and their collaboration with it. On the other hand, the existing barriers proved to be more permeable than expected, as we will see. On numerous occasions the established limits were transcended, and different groups (depending on the place and moment) occupied unforeseen spaces due to a certain permissibility on the part of the authorities, to gaps in authority in certain places, and also to created complicities in political, social, and economic arenas. In this sense, the measures adopted by the Spanish government in the 1880s and 1890s to change the balance of power in the provincial and municipal governments, the participation of some creoles and mestizos in the Manila city council, the importance acquired by the Chinese mestizo elites in Cebu, or the mandates of Emilio Terrero and Eulogio Despujol, which established a certain dialogue and understanding 
with the native population, serve as examples of this assertion (Elizalde 2018b; Huetz de Lemps 2017; Cullinane 2017; Sánchez 2010).

\section{Factors for Integration}

There were also arbitrary and subjective criteria that united the different population groups and facilitated integration processes, such as the degree of hispanization; the family and the incorporation, by marriage or by business, to important familial sagas; the instruction received and education shared in some institutions; the practice of Catholicism, with its numerous rituals and collective ceremonies; the social position and belonging to adequate social, economic, political, or even educational networks; the economic position and shared business interests; the official relations and membership in associations and other collective bodies; habits, social activities, clothing, and even the physical appearance and the possession of racial traits deemed admissible (Coo 2014; Aguilar 2016). All of these factors could open channels of inclusion and break down some of the barriers between different population groups. ${ }^{5}$

Marriage proved to be a strategic tool for improving social standing, gaining a more convenient legal status, and "laundering" lineages. It was the line of the legitimate father-Spanish, native, Chinese mestizo, or Chinese - that determined the category of children. When there were mixed marriages, the mother's line could only add a mestizo character that would be regarded differently according to individual circumstances. The status of women, while they were unmarried, was determined by that of their fathers and, after their marriage, by that of their husbands. After the wedding, women and their legitimate children from that marriage acquired the same status as their husbands, at least during the husbands' lifetime, while widows returned to their original condition. ${ }^{6}$ This theory was applied in most cases, but there were examples, such as that of the Barretto family (mestizos from India, of Portuguese origin) in which the male, upon arriving in the Philippines, married a woman from an economically and socially powerful creole family from Manila, the Ycaza; he asked for and obtained Spanish naturalization; and their children were regarded as Spanish creoles and were fully integrated with the colonial elite of the islands in the nineteenth century (AHN 1849, 1850-1851).

During the final decades of the nineteenth century new factors also occurred to transform the social categorization of various social groups. In 1884 the introduction of new personal identity documents (cédulas 
personales) brought an end to the traditional ethnic-fiscal categories. From that year onward, all people living in the Philippines, "regardless of race, nationality or sex, who were 18 or older," were compelled to acquire identification documents that categorized each one as a member of the first class, second class, third class, and so on up to fifteen of these classes, depending on the professional occupation and the economic activity of the individual. This rule covered all Spaniards-including all legal categories from peninsulares to creoles and Spanish mestizos - as well as natives and foreigners who had resided on the islands for over a year. There were a few exceptions: army and navy officers, clerics, gobernadorcillos, barangay chiefs, consuls, convicts, and scholarship holders, as well as outlaws and infidels, who lived separately from the colonial regime, and the Chinese, who were later to be subject to a specific tax regime. After the introduction of these identification documents the population was no longer distinguished on the basis of ethnic or national origin, at least as far as taxation was concerned. However, these features were still recorded in population censuses and other official documents and on birth, baptism, and marriage certificates. The new fiscal division was based on wealth, wages, and economic activity $(\mathrm{El}$ impuesto de las cédulas personales 1894).

In addition, the final decades of the nineteenth century witnessed the adoption of more lenient policies toward assimilation and the application in the Philippines of the same civil and criminal codes that were in force in Spain. Other remarkable measures were a greater separation between the executive and judicial powers; the adoption of a new trade code; the introduction of new levies on economic activity; the reform of the local administration through the appointment of civil governors and gobernadores politico-militares (politico-military governors) in the provinces and the abolition of the position of alcaldes mayores (provincial governors); the creation of city councils in several cities (Cebu, Iloilo, Batangas, Albay, Vigan, Nueva Cáceres, and Jaro), which opened new opportunities for social mobility for natives and mestizos; and the 1893 municipal reform in Luzon and the Visayas for villages with over 1,000 personal tax documents. These measures did not erase the differences between different population groups, but in some instances they led to a greater discretion by the respective authorities when they had to decide the place of each person, making the borders between the population categories more flexible (Huetz de Lemps 2017, 173-226). 


\section{People In-between}

Resil Mojares has pointed out several interesting examples of people who transcended the borders between different population groups. One was Pedro Paterno, who came from a wealthy Chinese mestizo family. He was a student at the Universities of Salamanca and Madrid and became a poet, novelist, and politician. He became the director of the first public library in the Philippines; played an important role in the pact of Biak-na-Bato, which put an end to the first phase of the Philippine Revolution; and was elected president of the Malolos Congress of 1898. At the same time, he was a friend of the Spanish president Emilio Castelar, of the overseas ministers Víctor Balaguer and Fernando de León, and of some governors general of the Philippines. He was even conferred the Order of Isabella the Catholic for his collaboration with the Spanish administration. However, as Mojares $(2006,11)$ has explained, during his long stay in Spain "he kept aloof from other Filipinos, conscious that he was wealthier, better connected, and more assimilated than the rest," and he did not fully integrate with the Filipino propagandists, as he defended his own idea about the future of the Philippine nation. He could have played an important role both among the Chinese mestizos as well as among the Filipino natives or the Spaniards, but ultimately he ended up feeling neither integrated with nor fully embraced in any of those categories even though he could have claimed to belong to several of them.

A second character was Trinidad H. Pardo de Tavera, who was of Spanish, Tagalog, and Chinese descent and was from a family of considerable wealth. He was highly educated, spent years as an expatriate in Paris, had good relations with Filipino propagandists in France, and established a close relation with the Spanish colonial administration when he returned to the Philippines in the 1880s. However, he always had an uneasy relation with power, and it was difficult to determine his real position (ibid., 121). As has been noted, Pardo de Tavera "was cast in a certain outsideness, by intersecting factors of race, class, education, personality, and politics" (ibid., 201). He was a cuarterón, three-fourths Spanish by blood, a Spanish mestizo, the offspring of a Philippine-born Spaniard and a mestiza who was part Tagalog, part European, and part Chinese. In status and appearance, he was more Spanish than mestizo in the eyes of many; but in race-conscious Manila he was not quite Spanish either, and he did not have the political ascendancy and social influence of peninsulares. However, the Filipino 
natives did not consider him as fully one of them (ibid., 202). But when he was invited by Spain's Council of Ministers to inherit his grandfather's title, he refused the invitation, saying that he preferred to be simply T. H. Pardo de Tavera, highlighting that he, "was a Filipino, not a Spaniard" (ibid., 157). In fact, he positioned himself as a Filipino and considered the Philippines his country. Mojares (ibid., 208) clarified, "He did not use the word [Filipino] in its early sense as español Filipino but the late-nineteenth-century sense of belonging to a community wider than just creoles," but he was never clearly integrated with any population group.

At the same time, the relative administrative, economic, and migratory weakness of Spanish colonial rule permitted the emergence and consolidation of autochthonous elites - native and mestizo - which were to play a greater economic, social, and political role in the colonial Philippines than in other European colonies. Some examples, first of a collective nature, can be seen. John Sidel (1994) has explained the case of a wealthy and welleducated urban, proprietary, ilustrado class dominated by Chinese mestizos, who drew considerable incomes from various commercial establishments in ports, served as contractors to the Spanish authorities, and acquired some colonial state monopolies. He has also remarked on the emergence of petty inquilino (leaseholder) dynasties that occupied local political offices and held the lucrative contracts to vast friar lands: the Aguinaldos of Kawit, the Tironas of Imus, the Cuencas of Bacoor, the Camposes of Dasmariñas, and so many others (ibid., 113-14). Cullinane (2003, 37-39) has added the cases of Filipino holders of university degrees, especially licentiates in jurisprudence (abogados) and medicine (médicos), who aspired to the series of posts that began with becoming a licensed attorney and culminated with an appointment as fiscal, judge (juez), or doctor (médico titular). He has also underlined the integration of many natives in the Spanish administration as officials and clerks (escribientes) (ibid.). In the same line, Mojares (2006, 500) has pointed out the particularities of the ilustrados, who were "developed in the belly of colonialism," who "were conscious that they were the leading elements of the colonized," and who "parlayed this 'in-between' position into a space of knowledge and power, authorizing them to speak for the dominated and excluded." As cultural translators, they had the privilege of access to both sides and of exercising their authority over all the population groups.

Aside from gobernadorcillos, principalías, cabezas de barangay (barangay chiefs), cuadrilleros (police officials), and other municipal officers, 
there were also many examples of individual persons who collaborated with and occupied posts in the colonial administration. For instance, there was Casimiro Camerino, a native who was integrated into the provincial militia as colonel and head of the Compañía de Guías de la Provincia de Cavite (Sidel 1994, 116). Demetrio Durano, a native with Chinese ancestors, became justice of the peace (juez de paz) in Danao (Cullinane 1994, 167). Sergio Osmeña, from a Chinese mestizo clan, studied law at Manila's University of Santo Tomás and worked as a court recorder of the Cebu Audiencia and as personal aide to the Spanish politico-military governor of Cebu (Mojares 1994, 315). Jose Damaso Gorricho was born in the Philippines and became quartermaster of the Spanish army; his grandfather was Basque, but he also had ancestors from different origins - Irish, Greek, and Tagalog; he married a Tagala from Cavite, Ciriaca Santos, a brilliant businesswoman who started supplying hay (zacate) to the Spanish cavalry and ended up, together with her husband, owning most of the property along Escolta Street in Binondo and accumulating a large fortune (Paredes 1994, 363-64); Gorricho was also credited with having established one of the earliest moneylending houses in the country (Mojares 2006, 123). Finally, there was Eugenio López, of Chinese mestizo origin and with a long family tradition as merchants, Iloilo and Negros sugar planters, small bankers, and some gobernadorcillos; he was a moving force behind the colonial government's investiture of an elected municipal council, the Ayuntamiento de Jaro, in 1891, where he served as regidor or councilor (McCoy 1994, 440-41). Aside from these examples, there were many other cases.

\section{Elements and Spaces for Encounter}

A contributing factor to the encounter between different population groups was the possibility of acquiring a primary, secondary, and university education in the Spanish Philippines, facilitating the incorporation of the different inhabitants to a common Hispanic culture. Existing educational institutions and incipient educational policies promoted by the colonial authorities led to the emergence of educated population segments, which resulted in the improved social and professional standing of these groups. This possibility blurred racial and social barriers and encouraged the inhabitants to get involved in professional activities in medicine, printing, publishing, and the mass media, in which different social groups often worked together regardless of their official status (Mojares 2017, 547-70; 
Cano 2011). In 1873 the overseas minister sent a file to the Consejo de Filipinas in order for this advisory institution to study the convenience of creating new positions for doctors in the Philippines. The Consejo's opinion, which was quite faithfully followed in the Royal Decree of 31 March 1876, recommended equalizing the number of titular doctors among Europeans and indigenous people, in order to allow natives and Chinese mestizos to join this profession that was so useful and necessary in the archipelago and, at the same time, offer a professional career to students of the Faculty of Medicine of the University of Santo Tomás (AHN 1874).

At the same time, the inability of the colonial administration to control effectively the entire archipelago also permitted the settlement of foreign communities, which were to play a crucial role in the ongoing transformation of the Philippines (Legarda 1999).

As a result of all these changes, new groups appeared and new forms of economic and professional solidarity crystallized, transcending the old colonial divisions and opening up new possibilities for social mobility.

The practice of Catholicism also influenced social stratification in the Spanish Philippines to the point that the native population was divided into Catholics and "infidels," the latter living apart from colonial society. Catholicism and the fact of sharing the same faith became essential elements for acceptance in that colonial society. A native or a Chinese mestizo who was conveniently Christianized and Hispanized in uses and customs and had a good economic and social standing could be incorporated into the colonial order easily if there were interest and reasons for this incorporation. At the same time, Catholic practices and attendance at the multiple ceremonies it entailed-rituals, processions, pilgrimages - created bridges between coreligionists. The British consul in Manila was of the opinion that "[w]ithin the church, the rites and ceremonies of the day ... are much what they might be in any small provincial town of Spain itself. But the music, contributed by a native brass band is not European merely. ... It is a religion admirably adapted to the requirements of the people and proportionately beneficial" (Palgrave 1973, 28-29). Catholicism, therefore, was a powerful instrument not only of evangelization but also of hispanization and integration (Wickberg 1964; Blanco 2009).

As we have seen, the different population groups interacted, then, in local government institutions and parishes as well as in other spaces of sociability, such as official ceremonies, religious rituals, committees, business meetings, afternoon walks, domestic social gatherings, public celebrations, 
and recreational events. They also related to each other in various economic activities that ranged from haciendas to commerce, from the rental of properties to the granting of loans or signatures before notaries. At the same time, mixed marriages and matrimonial and family strategies were common and a crucial way for creating closer links between groups.

Multiple examples of places for interaction and encounter between groups could be pointed out. I am going to refer to only three cases-an official ceremony, a fiesta in a village, and a meeting in a notary's office.

In July 1878, on the occasion of the death of Queen Mercedes, wife of King Alfonso XII, the corresponding mourning was organized in the Philippines, in which different peoples gathered at the Cathedral of Manila: the authorities of the colonial government from the governor general to the magistrates; the archbishop of Manila and representatives of religious orders; the rectors of universities and colleges; the gobernadorcillos and heads of barangays from the towns around Manila; the principales of each guild; and representatives of civil society, from directors of newspapers, banks, and associations to professionals, merchants, consuls, foreigners, and numerous individuals. Even the "general population" was invited, but assistance was limited for reasons of order (Exequias celebradas en Manila 1878).

In the fiestas of the villages in the countryside, the encounter between different population groups was also usual, as attested by numerous accounts of evenings of music, dances, meals, and conversations among natives, mestizos, creoles, peninsulares, and foreigners. These celebrations were reflected in numerous works written by foreign travelers in the nineteenthcentury Philippines and also in different Philippine novels, some as prominent as the Noli me tángere written by José Rizal. Let me take as an example a story written by the family of Pedro P. Róxas about a fiesta held on 24 June 1875 in Nasugbú, Batangas, in one of the family's haciendas. It was attended by a diverse group, from the principales and the inhabitants of the town to some colonial authorities and a group of people of different conditions: in addition to Roxas and a group of creoles and Spanish mestizos "the priest of the town, D. Melecio Zaividea, the Frenchman Hipólito Caylles with his wife and children, Captain Mateo Samaniego, his wife and daughters, captain Nena and Maria and daughters, and almost all the people of Nasugbú." The lieutenant and other officials of the Civil Guard also attended. They ate, drank, and danced; Caylles, who had been a member of the choir of the Maugard Opera Company, sang a piece from 
Barber of Seville. Later, they went "to the cockpit and dance was organized in several houses, dancing until late at night” (Fernández 1918, 82-83). These meetings, which had a festive and recreational character, not only made explicit spaces for coexistence and interaction but also reinforced ties of collaboration and dependence, maintained control and order in the haciendas, solved problems, and allowed people to engage in business and resolve business matters.

The third example of a space for encounter and interactions between different groups of the population is the scenario in the chambers of two notaries. On the first occasion, on 26 May 1866, the brothers Gregorio I, Gregorio II, and Paulino Avelino Nicolás, who were described as indios, got together with José Bonifacio Róxas, an español filipino, in the presence of the peninsular escribano (notary) Jayme Pujades, to execute a deed of sale of a lot in the suburb of San Miguel (NAP 1866). On the second occasion, on 23 June 1879, the escribano Francisco Hernández y Fajarnes, a peninsular; Pedro P. Róxas, a creole; and Joaquin Tan Angco and Yldefonso Sontua, Chinese, met to sign a deed acknowledging the payment of a loan of P10,000 (NAP 1879).

\section{The Public Arena}

Despite these spaces for interaction, differentiation or integration at a social level was somewhat arbitrary due to the malleability of the criteria used for acceptance, promotion, or social exclusion. Probably, politics remained in the public arena in which categories were observed most rigidly. This strategy was meant to keep political power in the hands of the Spanish and undermine the possible influence of groups that could pose a threat to Spanish sovereignty. It was, however, necessary to open new avenues of political participation for members of the local population, who were, in any case, generally limited to local government duties and advisory roles. If during the first decades of the century the possibility of electing deputies to the Spanish Cortes offered the conditions for limited political participation, during the second half this potential was realized by way of local administration, especially with the creation of new councils in the largest cities. The administrative reforms introduced during the final decades of the century changed the racial eligibility criteria for administrative posts, allowing natives, mestizos, creoles, and Spanish-born citizens alike to assume local responsibilities, without race 
being a determining factor. The response to these measures, however, was heterogeneous and often contradictory, depending on the place and the circumstances.

For instance, in the city council of Manila, the Spanish-both peninsulars and creoles - tried to defend their traditional privileges, which were being threatened by the political aspiration of new groups. However, the composition of the council, known in detail thanks to the works of Xavier Huetz de Lemps, reveals a progressive widening of its social composition: the legal and racial category required of a councilor could be considered with a certain laxity if the person was economically powerful, was markedly Hispanized, or belonged to networks of interests capable of blurring the ethnic origin and allowing incorporation into the ayuntamiento. However, this policy of greater openness resulted mainly in a wider presence of creoles compared with peninsulares. In 1893, of the eighty-nine individuals proposed by the Ayuntamiento de Manila for the position of regidor, forty were peninsulares, forty-eight were españoles filipinos or creoles, and one was a Cuban Spaniard. This composition expressed the will to offer the creoles a place in political life, preventing a dangerous sense of exclusion from spreading among the españoles filipinos. Moreover, in 1894 a Chinese mestizo, Luis Rafael Yangco y Ronquillo, was appointed regidor of the Manila city council. As Huetz de Lemps (2017, 173-226) has expressed vividly, it meant that the racial barrier fell and the most prestigious corporation of the archipelago was no longer a "closed box" for Spaniards.

At the same time, the new councils constituted in 1889 in five citiesAlbay, Batangas, Nueva Cáceres, Vigan, Cebu, and Iloilo-were created with the express ambition of incorporating other population groups. Perhaps the most interesting was the case of the city council of Cebu, well studied by Michael Cullinane. The Spanish presence on the island was limited, which allowed the corporation created in 1889 to become an arena in which different ethnic groups could coexist. Because Cebu had a large community of Chinese mestizos who had resided in the city for a long time and were thoroughly Hispanized, they became the most important community in Cebu such that in 1890 seven out of ten councilors were Chinese mestizos. They were also the richest community in the region and the most important urban and rural landowners, first through trade and later through the direct exploitation of haciendas and the export of agricultural products. In the second half of the nineteenth century, marriages became less endogamous, and Chinese mestizos, Spanish mestizos, and natives intermarried more 
frequently and regularly, promoting integration (Cullinane 2017, 295-324). Following Spanish custom, children inherited the category of the father, and women, upon marriage, acquired that of their husbands. Therefore, it was not rare for a Chinese mestizo woman who married a native to be regardedalongside her children - as a member of the gremio de naturales. By the same rule, a native woman who married a Chinese mestizo acquired her husband's status, and so did her children. This opened the possibility for a Chinese mestizo - and his children - to belong to one gremio, while his sister-and her children-belonged to another, which facilitated the integration of different communities, as Cullinane (ibid., 317) has well explained:

Among the many cases of siblings being enrolled in different gremios are the children of the Chino Cristiano Domingo Gandiongco: his eldest daughter Evarista Gandiongco married Estanislao Rafols, a Spanish Mestizo and later enrolled in the Gremio de Naturales, while her brother Gregorio Gandiongco married Barbara Normandia, a prominent member of the Gremio de Naturales, but remained in the Gremio de Mestizos Sangleyes. Three of Evarista's other siblings, Juana, Crescensio, and Ines Gandiongco, all married Chinese Mestizos and, as such, remained in the Mestizo Gremio.

The interactions at the political level were also revealed in critical situations, such as the events of Binondo in 1888 (AHN 1887-1888), the great demonstration of gobernadorcillos in the same year (AHN 1888), or the close relations established by certain governors, especially Emilio Terrero and Eulogio Despujol, with native principales (Elizalde 2018b). The metropolis and the most conservative sectors of the administration viewed this rapprochement between the colonial power and the indigenous authorities with suspicion, believing that it could threaten Spanish sovereignty. In the archipelago, however, these relationships were seen with great satisfaction, and it was believed that they could open the door to greater cooperation (Díez 1991; Blanco 2013, 2017; Elizalde 2016, 2018b).

\section{The Economic World}

At the economic level, the interactions among population groups were remarkably tight. Given the prevailing colonial regime, in many cases the methods of production, control of land, crops, and exports were imposed 
by those who had more or better control in running the economy. But, next to the role played by the colonial administration or the Spanish peninsulars in this field, soon creoles, mestizos, Chinese, and several groups of natives gained a burgeoning economic presence, and investment and trade became increasingly internationalized. Economic alliances, competition, and lobbies did not run along ethnic or legal lines, but were formed in response to common interests and strategic concerns. The relative position of Philippine-based groups-that is, groups that held a firm position in and were committed to the islands (which could include natives, mestizos, descendants of Spanish, or foreigners)-became even more important. Group alliances crystallized in the creation of a great variety of commercial firms, such as the San Miguel Brewery, Tranvías de Filipinas, Compañía Marítima, and other shipping companies, sugar-growing haciendas, abacaand other textile fiber-processing factories, construction companies, oils and alcohol factories, and multiple businesses as well as in other transactions such as loans (Legarda 1999; Elizalde 2017a).

Haciendas, which played such a prominent role in the growing importance of export agriculture during the nineteenth century, were another propitious sector for the crafting of alliances between disparate groups. In the past, indigenous principalías had organized the sowing and harvesting of the village lands, but the nineteenth-century haciendas imposed new ownership and exploitation regimes. This was, however, a highly heterogeneous world in which different economic systems and social organization models coexisted, as Filomeno Aguilar (2017, 101-36) and Alfred McCoy (2017, 137-70) have recently articulated for Calamba in Luzon and Negros in the Visayas. In both areas haciendas produced sugar for the international markets, but their organization was very different.

The Hacienda of Calamba, not far from Manila, was a large property owned by the Dominicans, which leased it out mostly to Chinese mestizos, who hired native laborers to work the land. The Dominicans merely collected the rent and invested very little in improving the hacienda. It was the tenant mestizos themselves who had to invest their own capital (or the capital of Chinese lenders or intermediaries who brought sugar to foreign merchants in Manila) and who bought tools and machinery to improve production (Aguilar 2017). When the tenants complained about a hike in the rents and the increasingly harsh working conditions, the colonial authorities sided with the Dominicans, which led to important clashes between the inhabitants 
of the islands and representatives of the colonial regime-a struggle that had clear political and racial undertones (APSR 1909, cited in Arcilla 1970, 577-633).

In Negros the land was in the hands of native principales and Chinese mestizos who, after the collapse of the traditional textile industries in Iloilo, left the city and bought small agricultural properties from independent peasants. They focused on sugar and on hiring native hands to work the land; this led to stark economic differences and a rigid social structure ruled by the sugar market. In Negros the modernization of production was assumed by the landowners, often after they had taken out loans from Iloilo-based foreign mercantile companies-including Spanish companies-operating in the international markets, which resulted in the installation of advanced sugar-processing factories. This process took place with little participation from the colonial administration. The landowners, the workmen, and the native, mestizo, and foreign exporters negotiated agreement and conflict (McCoy 2017; Aguilar 2017). Socially, Negros was divided into a few wealthy landowners and a great mass of poor workmen. Such division led to civil conflict and social unrest against the status quo, characterized by shifting alliances between groups. Ultimately, these tensions triggered a complex conflict, which became even more complicated because it coincided with the end of the Spanish colonial regime and the beginning of the American administration (Aguilar 1998).

This conflict was underpinned by a class component, which was also present in other conflicts from the early nineteenth century onward and was often marked by widespread discontent with the prevailing land ownership regime. The battle was no longer between colonizers and colonized, or about race and ethnicity, but rather about social and economic inequality and the distribution of wealth, property, labor, and social justice. These problems, which in other countries became especially severe during the final decades of the nineteenth century and the beginning of the twentieth century, were in the Philippines less prominent owing to the struggle against colonial domination, which forced different social sectors to unite against the Spanish and American administrations. The colonial problem and the struggle for independence thus postponed a problem which Philippine society was to confront further down the line, once full independence had been achieved (McCoy 2017). 


\section{Printing World}

Finally, in a homage dedicated to Resil Mojares, I could not but mention the alliances that were formed around the printing press, a subject on which Mojares (2017, 547-69) has completed much important work. As he has well explained, printing took off in the Philippines early. From the beginning of the colonization process, there was intense collaboration between Spanish missionaries and Philippine craftsmen in the printing of books. The 1593 publication of the book Doctrina Christiana en la lengua española y tagala, the first book to be printed in the archipelago, manifested this collaboration. Natives began to work together with the religious as printers, translators, and even authors. Perhaps the most famous among them was Tomás Pinpin, but many others followed him. In addition to working in cooperation with the colonizers, the natives soon began developing their own printing initiatives. This situation was probably related to the native printers' prominent role in the crystallization of a Philippine national conscience and in the struggle for independence.

The potential of the printing press, however, was not fully realized until the final decades of the nineteenth century, with the increase in the number of publications and the growing importance of newspapers. As Mojares (ibid.) has explained, there were fifty-three printing presses and ninety-eight periodical publications in the Philippines, which were no longer exclusively in the hands of religious orders as some were owned by peninsular, creole, mestizo, and native printers. The old portable printing press was superseded by professionally managed industrial enterprises that employed editors, designers, lithographers, engravers, bookbinders, and other workers; professional abilities were given priority over ethnic origin. Although it has been argued that the printing press and the newspapers were largely an instrument in the hands of the colonial state and the religious hierarchy, the truth is that, despite censorship, there was some degree of freedom, and the printing press was an efficient outlet for dissenting opinions. For a while, Spanish-born and creole printers dominated printing, but the participation of native personnel became increasingly important, and natives soon ascended the professional ladder and became editors, writers, and publicists, until ultimately they came to establish their own printing presses. Mojares has undertaken a detailed study of the relationship between the Spaniard Felipe del Pan, writer and editor of the three main Manila newspapers during the 
nineteenth century - the Diario de Manila, the Revista de Filipinas, and La Oceanía Española - and Isabelo de los Reyes, born in Vigan from creole and Chinese mestizo ancestors, typesetter in La Oceanía Española in his early years, and later journalist and specialist in Philippine folklore, as well as one of the leaders of the Philippine nationalist movement. This example helps Mojares to illustrate the emergence of a colonial intelligentsia in which the press and publications played a fundamental role, an intelligentsia that was well connected both to the metropolis and to other countries. Mojares (ibid., 563) concludes:

By the late nineteenth century, social and political instabilities had rendered binaries of race and political positions (Spaniard/native, reactionary/progressive, assimilationist/separatist) reductive and inadequate in capturing the realities of a history in dynamic motion. This was, after all, the time when Filipino was as yet a fluid marker of identity. The fact is that there were peninsular Spaniards and Creoles-like del Pan, Trinidad Pardo de Tavera, Juan Atayde, and Manuel Artigas-who, in varying ways, were or came to be called Filipinos. They were contributors to that climate of thought that would help prime the ground for a more nationalist and separatist politics.

Coinciding with the author's words, I would like to highlight the interactions between different population groups that took place in this professional field.

\section{Conclusion}

With this quotation from Resil Mojares I wish to end this contribution, which could go on for much longer if we included examples of modes of interaction in other spheres of life. In this article I have attempted to explain how Philippine colonial society cannot be viewed only in black and white terms, as a constant struggle between colonizers and colonized. There was an infinitely wide range of shades of gray where interaction and understanding were possible between different population groups. I have also attempted to convey that the barriers that separated these groups were a good deal more permeable than it seemed at first sight. These considerations are not to deny contradiction, abuse, and conflict-which are inseparable from colonial relationships - or the existence of groups that lived outside 
the margins of colonial administration and were beyond all attempts at integration. However, I would like to highlight that in a colonial regime, in this specific case in the Philippines, different groups managed to find ways to meet and collaborate beyond the legal, ethnic, and social classifications.

\title{
Abbreviations Used
}

\author{
AMAEP Archives du Ministère des Affaires Étrangères, Paris, France \\ AHN Archivo Histórico Nacional, Madrid, Spain \\ APSR Archivo de la Provincia del Santísimo Rosario, Manila, Philippines \\ exp. expediente \\ FHL-AF Filipinas Heritage Library, Ayala Foundation Inc., Manila, Philippines \\ leg. legajo \\ NAP National Archives of the Philippines, Manila, Philippines
}

\section{Notes}

This article is a revised version of a paper originally prepared for the "Bridging Worlds, Illumining the Archive: An International Conference in Honor of Resil B. Mojares" organized by Philippine Studies: Historical and Ethnographic Viewpoints, Ateneo de Manila University, and Southeast Asian Studies, Kyoto University, and held on 30-31 July 2018 at Novotel Manila Araneta Center, Quezon City. It has been written within the framework of the Spanish Research Project "La modernización de Filipinas, 1868-1898" (HAR2015-66511-P), funded by the National Plan of Research (Spain MINECO-FEDER).

1 Spanish historians, such as Antonio de Morga, Tomás de Comyn, Sinibaldo de Mas, Joaquín Martínez de Zúñiga, Manuel Buzeta y Felipe Bravo, Wenceslao Retana, José Montero y Vidal, J. F. Del Pan, Rafael Díaz Arenas, Rafael Comenge, Eduardo Navarro, and Juan Delgado, accurately described the division of the population into several social categories. Cf. Wickberg 1964; Phelan 1959, 95-97. On the Chinese population in the nineteenth century, cf. Wickberg 2001; Wilson 2004; Chu 2010.

2 After the signing of the treaty of friendship and trade between Spain and China in 1868, in theory the Chinese population in the Philippines came to be considered as foreigners who were to receive the same treatment as any other individual from the most favored nation, as the Madrid-based Consejo de Filipinas (Council of the Philippines) made it known to the governor general of the islands in July 1875 (AHN 1875).

3 See the excellent article by John Blanco 2011.

4 Libro 31 de Bautismos de la Parroquia del pueblo del Santísimo Rosario y San Gabriel de Binondo, 4 July 1861, Manila, Filipinas. The reference to Juana Lim de Castro appears in the Catalogue of Ayala-Zobel Archival Documents, Doc. no. 902-903, Filipinas Heritage Library, Ayala Foundation (FHL-AF), Manila, Philippines.

5 Elizalde and others 2019 have had occasion to verify these affirmations through the study of the Roxas family and of people with very diverse origins and conditions that were related to them. 
6 For widows, see the conclusions of Cullinane 2017, 295-324.

7 The interpretations of McCoy 2017 and Aguilar 2017 are summarized in the following paragraphs.

\section{References}

Aguilar, Filomeno V. Jr. 1998. Clash of spirits: The history of power and sugar planter hegemony on a Visayan island. Quezon City: Ateneo de Manila University Press.

_ 2016. Romancing tropicality: Ilustrado portraits of the climate in the late nineteenth century. Philippine Studies: Historical and Ethnographic Viewpoints 64(3-4): 417-54.

—. 2017. Capitalismo azucarero: Los caminos divergentes de las haciendas en la isla de Negros y en Calamba. In Filipinas, siglo XIX. Coexistencia e interacciones entre comunidades en el imperio español, ed. María Dolores Elizalde and Xavier Huetz de Lemps, 101-36. Madrid: Ed. Polifemo.

Aizpuru, Mikel. 2017. Insignificante átomo de la esfera social. La naturalización de chinos y otros extranjeros en las Filipinas Española. In Filipinas, siglo XIX. Coexistencia e interacciones entre comunidades en el imperio español, ed. María Dolores Elizalde and Xavier Huetz de Lemps, 32562. Madrid: Ed. Polifemo.

Amoroso, Donna J. 2003. Inheriting the "Moro problem": Muslim authority and colonial rule in British Malaya and the Philippines. In The American colonial state in the Philippines, ed. Julian Go and Anne L. Foster, 118-47. Durham: Duke University Press.

Archives du Ministère des Affaires Étrangères, Paris, Francia (AMAEP). 1896a. Correspondence politique des consuls. Nouvelle Série, Espagne, Illes Philippines. NS 30, Philippines. Consulate de France aux Philippines. Direction Politique, n. XCIII, 5 Sept.

—1896b. Correspondence politique des consuls. Nouvelle Série, Espagne, Illes Philippines. NS 30, Philippines. Consulate de France aux Philippines. Direction Politique, n. XCIII, 30 Sept.

Archivo de la Provincia del Santísimo Rosario (APSR). 1909. Apuntes sobre la Hacienda de Calamba, Fray Felipe Domínguez, Administrador de la Hacienda de Calamba, 26 Aug. Manila, tomo 608.

Archivo Historico Nacional (AHN). 1842. Letter from Domingo Roxas to General Espartero, "Regente del Reino," May. Ultramar, Gracia y Justicia, 2153, exp. 39.

_. 1849. Permiso de residencia en Manila para Bartolomé A. Barretto. Ultramar, 5161, exp. 53.

_-1850-1851. Concedida carta de naturaleza a B.A. Barretto. Ultramar, 5162, exp. 38.

—. 1874. Dictamen emitido por Pablo Ortiga y Rey y Fr. Pedro Payo, 19 Oct. Ultramar, 5305/2, exp. 22, n. 5.

—. 1875. Dictamen emitido por Manuel Azcárraga y Fr. Pedro Payo, 5 Jun. Ultramar, 5305/3, exp. 35.

1887-1888. El gobernadorcillo del gremio de mestizos de Binondo, recurre en queja con motivo de un Decreto del gobernador general sobre precedencia en los actos públicos. Ultramar, 2249, exp. 16 .

1888. Solicitudes de gobernadorcillos y principales de Luzón. Ultramar, 5258, exp. 53.

Arcilla, José. 1970. Documents concerning the Calamba deportations of 1891. Philippine Studies 18(3): 577-633 
Bankoff, Greg. 1992. Big fish in small ponds: The exercise of power in a nineteenth-century Philippine municipality. Modern Asian Studies 26(4): 679-700.

Barclay, Paul. 2003. They have for the coast dwellers a traditional hatred: Governing Igorots in northern Luzon and central Taiwan. In The American colonial state in the Philippines, ed. Julian Go and Anne L. Foster, 217-55. Durham: Duke University Press.

Blanco, John D. 2009. Frontier constitutions: Christianity and colonial empire in the nineteenth-century Philippines. Berkeley: University of California Press.

- 2011. Race as praxis in the Philippines at the turn of the twentieth century. Southeast Asian Studies 49(3): 356-39.

Blanco Andrés, Roberto. 2010. Pedro Peláez, leader of the Filipino clergy. Philippine Studies 58(1-2): $3-43$.

—. 2013. Entre frailes y clérigos. Las claves de la cuestión clerical en Filipinas. Madrid: CSIC.

_. 2017. Enfrentados con La Propaganda. El clero regular frente al nacionalismo filipino y la ofensiva anticlerical. In Filipinas, siglo XIX. Coexistencia e interacciones entre comunidades en el imperio español, ed. María Dolores Elizalde and Xavier Huetz de Lemps, 515-46. Madrid: Ed. Polifemo.

Bowring, John. 1876. Una visita a las islas Filipinas. Manila: Imp. de Ramirez y Giraudier.

Cano, Gloria. 2011. La Solidaridad y el periodismo en Filipinas en tiempos de Rizal. In Entre España y Filipinas, José Rizal, escritor, ed. María Dolores Elizalde, 171-201. Madrid: BNE-AECID.

Chu, Richard T. 2010. Chinese and Chinese mestizos of Manila: Family, identity, and culture, 1860s-1930s. Leiden/Boston: Brill.

Clarence-Smith, William. 2017. Migrantes del sur de Asia en Filipinas a lo largo del siglo XIX. In Filipinas, siglo XIX. Coexistencia e interacciones entre comunidades en el imperio español, ed. María Dolores Elizalde and Xavier Huetz de Lemps, 363-91. Madrid: Ed. Polifemo.

Constantino, Renato. 1969. The making of a Filipino: A story of Philippine colonial politics. Quezon City: Malaya Books.

_. 1985. Nationalism and the hero from Batac. Journal of Contemporary Asia 15:117-28.

Coo, Stephanie. 2014. Clothing and the colonial culture of appearances in nineteenth century Spanish Philippines (1820-1896). PhD thesis, Université de Nice Sophia-Antipolis.

Corpuz, O. D. 1989. The roots of the Filipino nation. Quezon City: Aklahi Foundation.

_. 1999. An economic history of the Philippines. Quezon City: University of the Philippines Press.

Cullinane, Michael. 1982. The changing nature of the Cebu urban elite in the $19^{\text {th }}$ century. In Philippine social history: Global trade and local transformations, eds. Alfred McCoy and Ed. C. de Jesus, 251-96. Quezon City: Ateneo de Manila University Press.

- 1994. Patron as client: Warlord politics and the Duranos of Danao. In An anarchy of families: State and family in the Philippines, ed. Alfred McCoy, 163-242. Quezon City: Ateneo de Manila University Press.

2003. Ilustrado politics: Filipino elite responses to American rule, 1898-1908. Quezon City: Ateneo de Manila University Press.

2013. The Parian of Cebu City: A historical overview, 1565-1898. Cebu City: Ramon Aboitiz Foundation. 
. 2017. Transformándose en Filipinos: Los mestizos chinos de Cebú. In Filipinas, siglo XIX. Coexistencia e interacciones entre comunidades en el imperio español, ed. María Dolores Elizalde and Xavier Huetz de Lemps, 295-324. Madrid: Ed. Polifemo.

De Jesus, Ed. C. 1980. The tobacco monopoly in the Philippines: Bureaucratic enterprise and social change, 1766-1880. Quezon City: Ateneo de Manila University Press.

Díez Muñiz, Adolfo. 1991. Binondo: Foco de conflicto político-religioso entre gremios de naturales y sangleyes. Hispania Sacra 43:647-76.

Doeppers, Daniel F. 2000. Evidence from the grave: The changing social composition of the populations of Metropolitan Manila and Molo, Iloilo, during later nineteenth century. In Population and history. The demographic origins of the modern Philippines, ed. Daniel F. Doeppers and Peter Xenos, 26577. Quezon City: Ateneo de Manila University Press.

El impuesto de las cédulas personales. 1894. Colección de "El Faro Administrativo". Manila: Imprenta de D.J. Atayde y Compañía.

Elizalde, María Dolores, ed. 2003. Las relaciones entre España y Filipinas, siglos XVI-XX. Madrid: CSICCasa Asia.

——. ed. 2009. Repensar Filipinas. Política. identidad y religión en la construcción de la nación filipina. Barcelona: Editorial Bellaterra.

—. 2012. Imperial transition in the Philippines: The making of a colonial discourse about Spanish rule. In Endless empire: Spain's retreat, Europe's eclipse, America's decline, ed. Alfred McCoy, Josep M. Fradera, and Stephan Jacobsen, 148-60. Madison: University of Wisconsin Press.

_. 2016. Emilio Terrero y Perinat, un reformista al frente del Gobierno General de Filipinas, 18851888. Revista Hispanoamericana 6:1-21.

. 2017a. Interacciones empresariales entre las elites urbanas filipinas: Barcos, tranvías, cervezas y aceites. In Filipinas, siglo XIX. Coexistencia e interacciones entre comunidades en el imperio español, ed. María Dolores Elizalde and Xavier Huetz de Lemps, 63-98. Madrid: Ed. Polifemo.

_ 2017b. Navegando entre comunidades: El caso del "español-filipino" Pedro P. Roxas y su entorno. In Filipinas, siglo XIX. Coexistencia e interacciones entre comunidades en el imperio español, ed. María Dolores Elizalde and Xavier Huetz de Lemps, 247-94. Madrid: Ed. Polifemo.

_. 2018a. Movilidad, mestizaje y significación de los criollos en las Filipinas del siglo XIX. In Redes imperiales: Intercambios, interacciones y representación política entre Nueva España, las Antillas y Filipinas, siglos XVII y XIX, ed. María Dolores Elizalde and Carmen Yuste, 205-32. Madrid: CSIC.

_ 2018b. Gobierno colonial y órdenes religiosas en Filipinas en las últimas décadas del siglo XIX: "Cuando la religión se convierte en un instrumento político." In Gobernar colonias, administrar almas. Poder colonial y órdenes religiosas en los imperios ibéricos (1808-1930), ed. Xavier Huetz de Lemps, Gonzalo Álvarez Chillida, and María Dolores Elizalde, 115-47. Madrid: Casa de Velázquez.

Elizalde, María Dolores and Xavier Huetz de Lemps. 2015. Un singular modelo colonizador: El papel de las órdenes religiosas en la administración española de Filipinas. Illes i Imperis 17:185-220.

. eds. 2017. Filipinas, siglo XIX. Coexistencia e interacciones entre comunidades en el imperio español. Madrid: Ed. Polifemo. 
Elizalde, María Dolores, Xavier Huetz de Lemps, Martin Rodrigo, and Ruth de Llobet. 2019. Los Roxas. historia de Filipinas en el siglo XIX a través de una familia criolla. Madrid: Marcial Pons.

Exequias celebradas en Manila por el eterno descanso de la Reina Dª María de las Mercedes. 1878. Crónica del ceremonial fúnebre observado por el Excmo. Ayuntamiento de esta M. N. y S. L. Ciudad siendo su Presidente el Excmo. Sr. D. Domingo Moriones y Corregidor Vicepresidente D. Francisco de P. Ripoll. Manila: n.p.

Fernández, Joaquín V. 1918. Breves apuntes biográficos, 1845-1917. San Sebastián: Tipografía de la Voz de Guipúzcoa.

Fradera, Josep M. 2016. La nación imperial (1750-1918): Derechos, representación y ciudadanía en los imperios de Gran Bretaña, Francia, España y Estados Unidos, vol. 2. Barcelona: Edhasa.

Guerrero, Milagros. 1977. Luzon at war: Contradictions in Philippine society, 1898-1902. PhD diss., University of Michigan.

Hau, Caroline. 2017. Elites and ilustrados in Philippine culture. Quezon City: Ateneo de Manila University Press.

Huetz de Lemps, Xavier. 2006. L'archipel des épices. La corruption de l'Administration espagnole aux Philippines (Fin XVIIle- Fin XIXe siècle). Madrid: Casa de Velázquez.

—. 2017. El ayuntamiento y la comunidad española de Manila en el siglo XIX. In Filipinas, siglo XIX. Coexistencia e interacciones entre comunidades en el imperio español, ed. María Dolores Elizalde and Xavier Huetz de Lemps, 173-226. Madrid: Ed. Polifemo.

- 2018. Los criollos en las Filipinas del siglo XIX: Una elite discreta. In Redes imperiales: Intercambios, interacciones y representación política entre Nueva España, las Antillas y Filipinas, siglos XVII y XIX, ed. María Dolores Elizalde and Carmen Yuste, 185-203. Madrid: CSIC.

Ileto, Reynaldo. 1979. Pasyon and revolution: Popular movements in the Philippines, 1840-1910. Quezon City: Ateneo de Manila University Press.

Javellana, René. 2017. Weaving cultures: The invention of colonial art and culture in the Philippines, 1565-1850. Quezon City: Ateneo de Manila University Press.

Joaquin, Nick. 2005. A question of heroes. Pasig City: Anvil.

Kalaw, Maximo. 1926. The development of Philippine politics, 1872 to 1920. Manila: Oriental Commercial.

Larkin, John A. 1982. Philippine history reconsidered: A socioeconomic perspective. American Historical Review 87:595-628.

_.1993. Sugar and the origins of modern Philippine society. Berkeley: University of California Press.

Legarda, Benito Jr. 1999. After the galleons: Foreign trade, economic change and entrepreneurship in the nineteenth-century Philippines. Quezon City: Ateneo de Manila University Press.

Llobet, Ruth de. 2011. Orphans of empire: Bourbon reforms, constitutional impasse, and the rise of Filipino Creole consciousness in an age of revolution. PhD. thesis, University of Wisconsin-Madison.

Luque, Miguel. 1997. En los confines del imperio. La frontera y la rivalidad moros versus castilas en la literatura hispano-filipina. Revista Complutense de Historia de América 23:209-46.

Luque, Miguel and José María Fernández Palacios. 2016. La estadística como instrumento de gobierno: las clasificaciones de los grupos indígenas de Filipinas a través de los censos poblacionales de los siglos XVIII y XIX. In Filipinas y el Pacífico. Nuevas miradas, nuevas reflexiones, ed. Salvador Bernabéu, 319-50. Sevilla: Editorial Universidad de Sevilla. 
McCoy, Alfred. 1994. Rent-seeking families and the Philippine state: A history of the Lopez family. In An anarchy of families: State and family in the Philippines, ed. Alfred McCoy, 429-535. Quezon City: Ateneo de Manila University Press.

2017. Formación de élites y revolución social en las Filipinas del siglo XIX. In Filipinas, siglo XIX. Coexistencia e interacciones entre comunidades en el imperio español, ed. María Dolores Elizalde and Xavier Huetz de Lemps, 137-70. Madrid: Ed. Polifemo.

McCoy, Alfred and Ed. de Jesus, eds. 1982. Philippine social history: Global trade and local transformations. Quezon City: Ateneo de Manila University Press.

Mojares, Resil. 1994. The dream goes on and on: Three generations of the Osmeñas. In An anarchy of families. State and family in the Philippines, ed. Alfred McCoy, 311-46. Quezon City: Ateneo de Manila University Press.

- 2006. Brains of the nation: Pedro Paterno, T. H. Pardo de Tavera, Isabelo de los Reyes and the production of modern knowledge. Quezon City: Ateneo de Manila University Press.

- 2017. Filipinos y españoles en el mundo colonial de la imprenta. In Filipinas, siglo XIX. Coexistencia e interacciones entre comunidades en el imperio español, ed. María Dolores Elizalde and Xavier Huetz de Lemps, 547-69. Madrid: Ed. Polifemo.

Montero y Vidal, José. 1886. El archipiélago filipino y las islas Marianas, Carolinas y Palaos. Madrid: Imprenta y Fundición Manuel Tello.

National Archives of the Philippines (NAP). 1820. Notario Clemente Covarrubias, S6b-S8, Testamento de Don Manuel Bonifacio Pitto, Manila, 19 Oct. Protocolos de Manila, 1821, tomo 1.

_. 1866. Escribano Jayme Pujades, fols. 101v-104. Protocolos de Manila, leg. 393, tomo 1.

—. 1879. Escribano Francisco Hernández y Fajarnes, fols. 998-1000. Protocolos de Manila, leg. 584 , tomo 1.

Nolasco, Clarita. 1970. The creoles in Spanish Philippines. Far Eastern University Journal 15(1-2): 186-88.

Owen, Norman. 1974. The principalía in Philippine history: Kabikolan, 1790-1898. Philippine Studies 22(3-4): 297-324.

_. 1984. Prosperity without progress: Manila hemp and material life in the colonial Philippines. Berkeley: University of California Press.

Palgrave, William Gifford. 1973. Life in the Philippines one hundred years ago. Manila: Jorge B. Vargas Filipiniana Foundation.

Paredes, Ruby R. 1994. Ilustrado legacy: The Pardo de Taveras of Manila. In An anarchy of families: State and family in the Philippines, ed. Alfred McCoy, 347-427. Quezon City: Ateneo de Manila University Press.

Phelan, John Leddy. 1959. The hispanization of the Philippines: Spanish aims and Filipino responses, 1565-1700. Madison: University of Wisconsin Press.

Retana, Wenceslao E. 1921. Diccionario de Filipinismos. New York-Paris: n.p.

Sánchez, Luis Ángel. 2010. Gobierno y administración del territorio en Filipinas, 1565-1898. In Poblar la inmensidad: Sociedades, conflictividad y representación en los márgenes del Imperio Hispánico, siglos XV-XIX, ed. Salvador Bernabéu, 465-532. Madrid: CSIC-Ed. Rubeo.

Schumacher, John N. 1981. Revolutionary clergy and the nationalist movement, 1850-1903. Quezon City: Ateneo de Manila University Press. 
- 1991. The making of a nation. Essays on nineteenth-century Filipino nationalism. Quezon City: Ateneo de Manila University Press.

1997. The Propaganda Movement: 1880-1895. The creators of a Filipino consciousness, the makers of the revolution. Quezon City: Ateneo de Manila University Press.

— 2011. The Cavite Mutiny: Toward a definitive history. Philippine Studies 59:55-81.

Sidel, John. 1994. Walking in the shadow of the big man: Justiniano Montano and failed dynasty building in Cavite. In An anarchy of families: State and family in the Philippines, ed. Alfred McCoy, 109-61. Quezon City: Ateneo de Manila University Press.

Thomas, Megan. 2012. Orientalists, propagandists, and ilustrados: Filipino scholarship and the end of Spanish colonialism. Minneapolis: University of Minnesota Press.

Warren, James Francis. 2002. Iranun and Balangingi: Globalization, maritime raiding and the birth of ethnicity. Singapore: Singapore University Press.

Wickberg, Edgar. 1964. The Chinese mestizo in Philippine history. The Journal of Southeast Asian History 5(1): 62-100.

_. 2001. The Chinese in Philippine life, 1850-1898. Quezon City: Ateneo de Manila University Press.

Wilson, Andrew R. 2004. Ambition and identity: Chinese merchant elites in colonial Manila. Honolulu: University of Hawai'i Press.

María Dolores Elizalde is scientific researcher, Instituto de Historia, Consejo Superior de Investigaciones Científicas (CSIC), Albasanz 26-28, 28037 Madrid, Spain. Her recent works include: Filipinas, siglo XIX: Coexistencia e interacción entre comunidades en el imperio español, coedited with Xavier Huetz de Lemps (2017); Gobernar colonias, administrar almas. Poder colonial y órdenes religiosas en la renovación de los imperios ibéricos (1808-1930), coedited with Xavier Huetz de Lemps and Gonzalo Álvarez Chillida (2018); Redes imperiales: intercambios, interacciones y representación política en Nueva España, las Antillas y Filipinas, siglos XVIII Y XIX, coedited with Carmen Yuste (2018); Los Roxas. Historia de Filipinas en el siglo XIX a través de una familia criolla, coauthored with Xavier Huetz de Lemps, Martín Rodrigo, and Ruth de Llobet (2019). Her areas of research are the history of the Philippines and the Pacific, colonial societies, the Spanish empire, and the history of international relations.<lola.elizalde@cchs.csic.es> 